\title{
Surgical correction of mitral insufficiency due to integrity damage of chordal-papillary continium: comparison of long-term results
}

\author{
Bolshak O. O., Mnishenko V. I., Trembovetska O. M., Beshlyaga V. M., Leoshko I. V., \\ Popov V.V.
}

\author{
National M. M. Amosov Institute of Cardiovascular Surgery National Academy of Medical Sciences \\ of Ukraine (Kyiv)
}

\begin{abstract}
The authors present their results concerning surgical treatment of 520 patients using surgical correction of mitral insufficiency due to integrity damage of chordal-papillary continium. All the patients were operated using cardiopulmonary bypass in the period from 01.01.2006-31.12.2015 in different departments of the Mykola Amosov National Institute of Cardiovascular Surgery (Academy of Medical Sciences of Ukraine). All the patients examined were divided into two groups - group A (with mitral valve plastics) and group B (with mitral valve replacement, MVR). Long-term results became known for 487 patients (93.8\% of patients discharged).
\end{abstract}

Key words: mitral valve plastics, mitral valve replacement (MVR), chordal-papillary apparatus, long-term results

Mitral valve insufficiency due to integrity damage of this valve chordal-papillary continium appears in $9-17 \%$ of all cases of mitral defects, reaching $32-41 \%$ in the structure of mitral insufficiency $[1,7,8]$.

Chords and papillary muscles of the mitral valve being absolutely anatomically interrelated form a unique closed power circuit of the heart left ventricle: fibrous ring - leaflets - chords - papillary muscles - left ventricle myocardium fibrous ring. Any damage of fibrous ring integration leads to mitral valve unclosing which induces, in turn, the mitral valve regurgitation $[1,4,5,6]$.

In cardiologist's patients with "pure" or predominant mitral insufficiency, the hemodynamics disturbances are due to blood regurgitation through damaged mitral valve during ventricle systoles. The mass of reverse blood flow is determined by the pressure difference between atrium and ventricle as well as by the area of unclosing zone between valve leaflets. The volume overloading in the left atrium leads to the left ventricle volume overloading; it causes later its dilatation and hypertrophy. The complete fluid removal from the left atrium during diastole and push-like blood entrance into it leads to the situation when the increase of mean atrium pressure is lower than the increase found in cases of mitral stenosis; thus, the Kitayev's reflex switches on later being more weaker than in case of mitral stenosis. The pressure increase in the left atrium accompanied by the blood congestion in the lesser circulation are due to increased residual blood volume in it. As far as pulmonary hypertension progresses, the right ventricle insufficiency and the greater circulation insufficiency increase $[1-3,5,8,9]$.

Thus, the choice problem of the most effective approach for surgical treatment of the given pathology is a rather burning one.
The aim of this work is analysis of long-term results of surgical correction in cases of mitral valve insufficiency due to integrity damage of chordal-papillary apparatus when different surgical approaches had been used.

Materials and methods. During the period from the 01.01.2006 up to the $31.12 .2015,520$ patients with mitral insufficiency due to the integrity damage of chordal-papillary continuum were operated at the Mykola Amosov Institute of Cardiovascular Surgery (National Academy of Medical Sciences of Ukraine). Patients with accompanying aortal valve prosthetics were excluded from this study. The study included 367 males (70.6\%) and 153 females (29.4\%). Mean age of patients was $55.9 \pm 9.9$ years. Mitral valve plastics was carried out in 201 patients (38.7\%, group A), mitral valve prosthetics having been realized for 319 patients (61.3\%, group B). Two patients included to the group B had previously mitral valve plastics operation; however, the necessity of mitral valve replacement developed immediately during their stay in the hospital; thus, these patients were taken to the group B.

For examination of long-term results of operations, the authorsusedanamnestic,statisticalmethods, echocardiography, electrocardiography, endovascular examination approaches, questionnaires, corresponding, telephone calls etc.

The main information concerning our patients is given in the Table 1.

Among patients of A and B groups there was no significant differences concerning their gender and age; however, such differences are evident concerning insufficiency duration, presence of atrial fibrillation, and duration of such defect; these parameters as well as quantity of patients with the IV functional NYHA class were significantly higher in patients with mitral valve replacement, the pre-operational state of the group B patients was more serious. 


\section{Table 1}

The main data concerning pre-operation parameters of patients belonging to groups $A$ and $B$

\begin{tabular}{|c|c|c|c|c|c|}
\hline \multirow[b]{2}{*}{ Parameters } & \multicolumn{2}{|c|}{$\begin{array}{l}\text { Group A } \\
(n=201)\end{array}$} & \multicolumn{2}{|c|}{$\begin{array}{l}\text { Group B } \\
(n=319)\end{array}$} & \multirow[b]{2}{*}{$\mathbf{P}$} \\
\hline & $n$ & $\%$ & $n$ & $\%$ & \\
\hline Men & 144 & 71,6 & 223 & 69,9 & $>0,05$ \\
\hline Women & 57 & 28,4 & 96 & 30,1 & $>0,05$ \\
\hline Mean patient age (years) & \multicolumn{2}{|c|}{$55,1 \pm 9,2$} & \multicolumn{2}{|c|}{$56,5 \pm 10,1$} & $>0,05$ \\
\hline $\begin{array}{l}\text { Insufficiency duration } \\
\text { (years) }\end{array}$ & \multicolumn{2}{|c|}{$5,7 \pm 2,8$} & \multicolumn{2}{|c|}{$7,8 \pm 4,5$} & $<0,05$ \\
\hline Atrial fibrillation & 40 & 19,9 & 91 & 28,5 & $<0,05$ \\
\hline $\begin{array}{l}\text { Duration of atrial } \\
\text { fibrillation (years) }\end{array}$ & \multicolumn{2}{|c|}{$4,3 \pm 0,9$} & \multicolumn{2}{|c|}{$8,2 \pm 2,5$} & $<0,05$ \\
\hline $\begin{array}{l}\text { Functional NYHA class } \\
\text { II } \\
\text { III } \\
\text { IV }\end{array}$ & $\begin{array}{c}60 \\
102 \\
39\end{array}$ & $\begin{array}{l}29,9 \\
50,7 \\
19,4\end{array}$ & $\begin{array}{c}63 \\
150 \\
106\end{array}$ & $\begin{array}{l}19,7 \\
47,0 \\
33,2\end{array}$ & $\begin{array}{l}<0,05 \\
>0,05 \\
<0,05\end{array}$ \\
\hline
\end{tabular}

*Duration of atrial fibrillation before operation is known for 17 patients from the group A $(42.5 \%)$ and 48 ones from the group B (52.7\%).

\section{Table 2}

Main pre-operation echocardiography parameters

\begin{tabular}{lccc} 
Parameter & $\begin{array}{c}\text { Group A } \\
(\mathbf{n}=\mathbf{2 0 1})\end{array}$ & $\begin{array}{c}\text { Group B } \\
\mathbf{( n = 3 1 9 )}\end{array}$ & P value \\
\hline LV EDV $(\mathrm{ml})$ & $200,5 \pm 46,4$ & $210,3 \pm 48,4$ & $>0,05$ \\
\hline LV ESV $(\mathrm{ml})$ & $78,1 \pm 24,3$ & $88,6 \pm 26,8$ & $>0,05$ \\
\hline LV SV $(\mathrm{ml})$ & $123,2 \pm 34,5$ & $122,1 \pm 38,7$ & $>0,05$ \\
\hline LV EF $(\%)$ & $61,9 \pm 12,5$ & $58,9 \pm 14,0$ & $>0,05$ \\
\hline LV diameter $(\mathrm{cm})$ & $5,1 \pm 1,3$ & $5,3 \pm 1,4$ & $>0,05$ \\
\hline SPPA $(\mathrm{mm} \mathrm{Hg})$ & $52,2 \pm 15,3$ & $53,1 \pm 15,1$ & $>0,05$
\end{tabular}

The data seen in the Table 2 show no significant difference between echocardiography parameters of both groups; however, dilatation of left heart parts in the group B patients was somewhat more, the left ventricle contractility being somewhat lower.

Besides mitral insufficiency correction, accompanying surgical procedures were carried out for some patients (see Table 3).

According to the data presented in the Table 3 , tricuspid valve plastics operations were oftener carried out for patients of the group $\mathrm{A}$, the operations being mostly prophylactic ones in cases of small or moderate regurgitation. On the contrary, coronary artery heart disease requiring coronary bypass grafting was oftener found in group B patients ( $21.0 \%$ versus $12.4 \%$ of cases) suggesting the state of this group patients to be more severe.

The main parameters describing operations are shown in the Table 4.
Table 3

Accompanying surgical interventions aiming mitral insufficiency correction

\begin{tabular}{|c|c|c|c|c|c|}
\hline \multirow{2}{*}{$\begin{array}{l}\text { Accompanying } \\
\text { interventions }\end{array}$} & \multicolumn{2}{|c|}{$\begin{array}{l}\text { Group A } \\
(n=201)\end{array}$} & \multicolumn{2}{|c|}{ Group B $(n=319)$} & \multirow{2}{*}{$\begin{array}{c}P \\
\text { value }\end{array}$} \\
\hline & $\mathbf{n}$ & $\%$ & $\mathbf{n}$ & $\%$ & \\
\hline $\begin{array}{l}\text { Left atrium (LA) } \\
\text { plastics, MAZE }\end{array}$ & - & - & 17 & 5,3 & - \\
\hline $\begin{array}{l}\text { Tricuspid valve } \\
\text { (TV) plastics } \\
\text { including LA } \\
\text { plastics, MAZE }\end{array}$ & $\begin{array}{c}104 \\
4\end{array}$ & $\begin{array}{c}51.7 \\
2.0\end{array}$ & $\begin{array}{c}82 \\
4\end{array}$ & $\begin{array}{c}25,7 \\
1,3\end{array}$ & $\begin{array}{l}<0.05 \\
>0.05\end{array}$ \\
\hline $\begin{array}{l}\text { Coronary bypass } \\
\text { grafting }\end{array}$ & 8 & 4.0 & 47 & 14.7 & $<0.05$ \\
\hline $\begin{array}{l}\text { TV plastics + } \\
\text { coronary bypass } \\
\text { grafting }\end{array}$ & 17 & 8.4 & 20 & 6.3 & $>0.05$ \\
\hline Other & 7 & 3.5 & 5 & 1.6 & $<0.05$ \\
\hline In all: & 136 & 67.7 & 171 & 53.6 & $<0.05$ \\
\hline
\end{tabular}

Table 4

Duration of aorta clamping and artificial circulation

\begin{tabular}{|c|c|c|c|}
\hline Parameter & $\begin{array}{l}\text { Group A on the } \\
\text { whole }(n=201)\end{array}$ & $\begin{array}{l}\text { Group B on the } \\
\text { whole }(n=319)\end{array}$ & $\mathbf{P}$ \\
\hline $\begin{array}{l}\text { Aorta clamping } \\
\text { (min) }\end{array}$ & $110.5 \pm 38.8$ & $87.1 \pm 22.5$ & $<0.05$ \\
\hline \multirow[t]{2}{*}{$\begin{array}{l}\text { Cardiopulmonary } \\
\text { bypass (min) }\end{array}$} & $171,6 \pm 49,3$ & $136.8 \pm 31.7$ & $<0.05$ \\
\hline & $\begin{array}{l}\text { Group A patients } \\
\text { with TV plastics } \\
\quad(n=104)\end{array}$ & $\begin{array}{c}\text { Group B patients } \\
\text { with TV plastics } \\
\qquad(n=82)\end{array}$ & \\
\hline $\begin{array}{l}\text { Aorta clamping } \\
\text { (min) }\end{array}$ & $113.8 \pm 37.7$ & $95.7 \pm 27.2$ & $<0.05$ \\
\hline \multirow[t]{2}{*}{$\begin{array}{l}\text { Cardiopulmonary } \\
\text { bypass (min) }\end{array}$} & $173.7 \pm 48$ & $150.3 \pm 39.4$ & $<0.05$ \\
\hline & $\begin{array}{c}\text { Group A patients } \\
\text { with coronary } \\
\text { bypass grafting } \\
(n=8)\end{array}$ & $\begin{array}{c}\text { Group B patients } \\
\text { with coronary } \\
\text { bypass grafting } \\
(n=47)\end{array}$ & \\
\hline $\begin{array}{l}\text { Aorta clamping } \\
\text { (min) }\end{array}$ & $102.8 \pm 29.8$ & $112.4 \pm 28.3$ & $>0.05$ \\
\hline \multirow[t]{2}{*}{$\begin{array}{l}\text { Cardiopulmonary } \\
\text { bypass (min) }\end{array}$} & $159.6 \pm 40.5$ & $176.7 \pm 47.1$ & $<0.05$ \\
\hline & $\begin{array}{l}\text { Group A patients } \\
\text { with TV plastics } \\
\text { and coronary } \\
\text { bypass grafting } \\
\quad(n=17)\end{array}$ & $\begin{array}{l}\text { Group A patients } \\
\text { with TV plastics } \\
\text { and coronary } \\
\text { bypass grafting } \\
(n=20)\end{array}$ & \\
\hline $\begin{array}{l}\text { Aorta clamping } \\
\text { (min) }\end{array}$ & $141.8 \pm 38.4$ & $135.0 \pm 35.6$ & $>0.05$ \\
\hline $\begin{array}{l}\text { Cardiopulmonary } \\
\text { bypass (min) }\end{array}$ & $220.6 \pm 51.1$ & $200.9 \pm 46.3$ & $<0.05$ \\
\hline
\end{tabular}


Table 5

Diameters of prostheses implanted in group $B$ patients $(n=319)$

\begin{tabular}{lcc} 
Diameter of prostheses & $\mathbf{n}$ & \% \\
\hline $25 \mathrm{~mm}$ & 7 & 2.2 \\
\hline $27 \mathrm{~mm}$ & 97 & 30.4 \\
\hline $27 \backslash 29 \mathrm{~mm}(\mathrm{On}-\mathrm{X})$ & 35 & 11.0 \\
\hline $28 \mathrm{~mm}$ & 1 & 0.3 \\
\hline $29 \mathrm{~mm}$ & 165 & 51.7 \\
\hline $31 \mathrm{~mm}$ & 13 & 4.1 \\
\hline No data & 1 & 0.3
\end{tabular}

The duration of aorta clamping and cardiopulmonary bypass was longer in almost all patient subgroups of plastics group; this fact may suggest the plastics approach to be more complicated than the prosthetics one (Table 4).

Among the group B patients, the next models of mechanical artificial valves were implanted: On-x (45 cases, 14.1\%), Edwards Mira (20 cases, 6,3\%), Saint Jude Medical (173 cases, $54.2 \%$ ), Carbomedics (26 cases, $8.2 \%$ ), ATS (44 cases, 13.8\%), Medinzh (Russia), 1 case, $0.3 \%$ ), unknown models $(6,1,9 \%)$. Bioprostheses (3 prostheses from Edwards and 1 prosthesis from Saint Jude Medical) were implanted to 4 patients $(1.2 \%)$. Diameters of these implanted prostheses are the following (see the Table 5).

Among the group A patients, supporting rings or semirings for mitral annuloplastics were used in 178 cases $(88.5 \%)$, suture annuloplastics having been carried out in 15 cases (7.5\%); in 8 patients (4.0\%) no annuloplastics was used. Artificial chord formation and chord translocation were realized in 21 cases $(10.4 \%)$ and 4 cases $(2.0 \%)$, respectively. The following models of supporting rings were used: Edwards (77, 38.3\%), Saint Jude Medical (75, 37.3\%), SARP $(5,2.5 \%)$, Sorin $(2,1.0 \%)$; there is no information concerning such rings in 16 case $(8.0 \%)$; semi-rings were

\section{Table 7}

Histological investigation of mitral valve

\begin{tabular}{|c|c|c|c|c|c|}
\hline \multirow[b]{2}{*}{ Etiology } & \multicolumn{2}{|c|}{$\begin{array}{l}\text { Group A } \\
(n=157)\end{array}$} & \multicolumn{2}{|c|}{$\begin{array}{l}\text { Group B } \\
(n=293)\end{array}$} & \multirow[b]{2}{*}{$\mathbf{p}$} \\
\hline & $\mathbf{n}$ & $\%$ & $\mathbf{n}$ & $\%$ & \\
\hline $\begin{array}{l}\text { Fibro-elastic insufficiency } \\
\text { (including also the } \\
\text { Barlow's disease) }\end{array}$ & 51 & 32.5 & 89 & 30.4 & $>0,05$ \\
\hline $\begin{array}{l}\text { Dysplasia of leaflets, } \\
\text { chords (including small } \\
\text { innate anomalies) }\end{array}$ & 79 & 50.3 & 152 & 51.9 & $>0.05$ \\
\hline $\begin{array}{l}\text { Age-related changes } \\
\text { (fibrosis, lipoidosis, } \\
\text { calcification) }\end{array}$ & 21 & 13.4 & 41 & 14.0 & $>0.05$ \\
\hline Rheumovalvulitis & 6 & 3.8 & 11 & 3.7 & $>0.05$ \\
\hline
\end{tabular}

Table 6

Diameters of supporting rings in group A patients ( $n=175)$

\begin{tabular}{lcc} 
Supporting ring diameter & $\mathbf{n}$ & \% \\
\hline $26 \mathrm{~mm}$ & 4 & 2.3 \\
\hline $28 \mathrm{~mm}$ & 71 & 40.1 \\
\hline $29 \mathrm{~mm}$ & 8 & 4.6 \\
\hline $30 \mathrm{~mm}$ & 65 & 37.1 \\
\hline $31 \mathrm{~mm}$ & 1 & 0.6 \\
\hline $32 \mathrm{~mm}$ & 14 & 8.0 \\
\hline $34 \mathrm{~mm}$ & 5 & 2.9 \\
\hline $36 \mathrm{~mm}$ & 2 & 1.1 \\
\hline No data & 5 & 2.9
\end{tabular}

taken in 3 cases (1.5\%). Supporting rings of following diameters were implaned (see Table 6).

Histological mitral valve examination was carried out for 450 cases ( $86.5 \%$ of the patients operated) including 157 group A patients ( $78.1 \%$ of patients operated) and 293 group B patients $(91.8 \%$ of patients operated) $(p<0.05)$. The histological data obtained are shown in the Table 7.

The results given in the Table 7 do not show any significant difference concerning the etiology of mitral insufficiency due to integrity damage of chordal-papillary apparatus, i.e. between patients of $\mathrm{A}$ and $\mathrm{B}$ groups.

One patient of the group B died in the hospital (mortality level in this group is $0.3 \%$, the total mortality being $0.2 \%$ ).

Long-term results and discussion. We followed up the operation results in the long-term period for 487 patients (93.8\% of patients discharged); 192 of patients discharged (95.5\%) belong to the group A and 295 ones (92.5\%) to the group B. It is evident the situation in our country influenced significantly on these figures: 20 patients from 32 ones having been lost for our long-term period information live on the territory of the Crimea. Our mean follow-up duration reaches $6.3 \pm 2.6$ years.

The long-term results were evaluated using the next criteria: good, satisfactory, unsatisfactory, dead. Good results of the valve prosthetics were registered in cases of valve dysfunction absence, the SPPA being $\leq 30$ $\mathrm{mm} \mathrm{Hg}$; in these cases the sinus rhythm was seen, the LVEF value was $\geq 55 \%$; there were no re-operations or thromboembolic complications. Good results of the valve plastics were registered in cases of the mitral valve diastolic gradient was $\leq 5 \mathrm{~mm} \mathrm{Hg}$, the SPPA being $\leq 30 \mathrm{~mm} \mathrm{Hg}$; in these cases the sinus rhythm was seen, the LVEF value was $\geq 55 \%$; there were no re-operations or thromboembolic complications..

The results of the valve prosthetics were thought to be satisfactory in cases of atrial fibrillation absence, the SPPA being $30-50 \mathrm{~mm} \mathrm{~mm} \mathrm{Hg}$; in these cases the LVEF value was 40-55\%; there were no re-operations and thromboembolic complications. The results of mitral valve plastics were evaluated as satisfactory ones in cases 
Большак О. О. / Порівняльна оцінка віддалених результатів методик хірургічної корекції мітральної ...

Table 8

Long-term results of mitral valve replacement and plastics

\begin{tabular}{|c|c|c|c|c|c|c|c|}
\hline \multirow[b]{2}{*}{ Results } & \multicolumn{2}{|c|}{$\begin{array}{l}\text { Group A } \\
(n=192)\end{array}$} & \multicolumn{2}{|c|}{$\begin{array}{l}\text { Group B } \\
(n=295)\end{array}$} & \multirow[b]{2}{*}{$p$} & \multicolumn{2}{|c|}{$\begin{array}{c}\text { In all: } \\
(n=487)\end{array}$} \\
\hline & $\mathbf{n}$ & $\%$ & $\mathbf{n}$ & $\%$ & & $\mathbf{n}$ & $\%$ \\
\hline Good & 45 & 24,0 & 73 & 24.7 & $>0.05$ & 118 & 24.2 \\
\hline Satisfactory & 106 & 55.2 & 166 & 56.3 & $>0.05$ & 272 & 55.8 \\
\hline Unsatisfactory & 32 & 16.6 & 24 & 8.1 & $<0.05$ & 56 & 11.5 \\
\hline $\begin{array}{l}\text { Deaths of } \\
\text { patients }\end{array}$ & 9 & 4.7 & 32 & 10.8 & $<0.05$ & 41 & 8.4 \\
\hline
\end{tabular}

of the mitral valve diastolic gradient was 6-9 $\mathrm{mm} \mathrm{Hg}$, the SPPA being 30-50 $\mathrm{mm} \mathrm{Hg}$; in these cases the presence of atrial fibrillations was seen; the LVEF value was 40$55 \%$; there were no re-operations or thromboembolic complications.

Unsatisfactory prosthetics results were registered in cases of prosthesis dysfunction, the diastolic pressure gradient being $>20 \mathrm{~mm} \mathrm{Hg}$ accompanied by moderate and higher valve insufficiency; in these cases the LVEF value was < $40 \%$; re-operations were carried out or were necessary; there were thromboembolic complications and significant heart failure. Unsatisfactory plastics results were found in cases of diastolic pressure gradient $\geq 10 \mathrm{~mm} \mathrm{Hg}$, moderate and higher regurgitation on the valve,), LVEF value < $40 \%$; in these cases re-operations were carried out or were necessary; there were thromboembolic complications and significant heart failure.

The long-term results are presented in the Table 8 .

The data presented in the Table 8 indicate the quantity of good and satisfactory long-term results in both groups to be approximately the same. However, in prosthetics group the quantity of deaths in the long-term period is higher, the quantity of unsatisfactory results being more in the plastics group. Five group A patients $(2.5 \%)$ were re-operated in the long-term period (4 cases of the MVR operation, 1 case of mitral valve re-plastics); in 4 cases the patients were operated because of significant mitral insufficiency, 1 patient was re-operated because of post-operational infectious endocarditis of mitral valve. Re-operations were also carried out in 5 group B patients (1.6\%); such re-operations are reMVR (4 cases). tricuspid plastics ( 1 case); 3 patients were victims of prosthesis infectious endocarditis; 1 patient had a complication - thrombosis of mitral prosthesis; 1 patient was operated because of significant tricuspid insufficiency.

Causes of lethal cases in the long-term period are described in the Table 9.

Contrary to the group B patients, no lethal consequences due to thromboembolic complications were seen among the group A patients during the long-term period. However, among the group A patients with mitral valve plastics 3 cases of sudden death were registered in
Table 9

Causes of lethal cases

\begin{tabular}{|c|c|c|c|c|c|}
\hline \multirow[b]{2}{*}{ Cause } & \multicolumn{2}{|c|}{ Group A (n=9) } & \multicolumn{2}{|c|}{ Group B $(n=32)$} & \multirow[b]{2}{*}{$\mathbf{P}$} \\
\hline & n & $\%$ & $\mathbf{n}$ & $\%$ & \\
\hline $\begin{array}{l}\text { Thromboembolic } \\
\text { complications }\end{array}$ & - & - & 13 & 40.6 & - \\
\hline $\begin{array}{l}\text { Progressive heart } \\
\text { failure }\end{array}$ & 2 & 22.2 & 9 & 28.1 & $>0.05$ \\
\hline $\begin{array}{l}\text { Infectious } \\
\text { complications } \\
\text { (re-operations) }\end{array}$ & 1 & 11.1 & 1 & 3.1 & $>0.05$ \\
\hline Sudden death & 3 & 33.3 & - & - & - \\
\hline Unknown & - & - & 5 & 15.6 & - \\
\hline Oncology & 2 & 22.2 & 3 & 9.4 & $<0.05$ \\
\hline Other & 1 & 11.1 & 1 & 3.1 & $>0.05$ \\
\hline
\end{tabular}

Table 10

Causes of unsatisfactory results during the long-term period

\begin{tabular}{|c|c|c|c|c|c|}
\hline \multirow[b]{2}{*}{ Cause } & \multicolumn{2}{|c|}{$\begin{array}{c}\text { Group A } \\
(n=32)\end{array}$} & \multicolumn{2}{|c|}{$\begin{array}{c}\text { Group B } \\
(n=24)\end{array}$} & \multirow[b]{2}{*}{$\mathbf{P}$} \\
\hline & $\mathbf{n}$ & $\%$ & $\mathrm{n}$ & $\%$ & \\
\hline $\begin{array}{l}\text { Thromboembolic } \\
\text { complications }\end{array}$ & 1 & 3.1 & 11 & 45.8 & $<0.05$ \\
\hline $\begin{array}{l}\text { Progressive heart } \\
\text { failure }\end{array}$ & 1 & 3.1 & 6 & 25.0 & $<0.05$ \\
\hline Re-operations & 4 & 12.5 & 4 & 16.7 & $>0.05$ \\
\hline $\begin{array}{l}\text { Mitral valve } \\
\text { (prosthesis) } \\
\text { dysfunction }\end{array}$ & 26 & 81.2 & 3 & 12.5 & $<0.05$ \\
\hline
\end{tabular}

the long-term period on the background of satisfactory patients' state; these deaths causes are thought to be arrhythmias. Lethal cases frequency associated with heart failure and infectious complications was detected to be almost the same in both groups.

Information concerning unsatisfactory results of operations is given in the Table 10.

According to the data presented in the Table10, unsatisfactory results of the long-term period among MVR patients are mostly due to thromboembolic complications and progressing cardiac insufficiency. Simultaneously, damages of mitral valve function (increased gradient associated with the moderate stenosis development, moderate and higher regurgitation) are rather mostly detected in patients following plastics operations.

During the long-term follow-up, 1 case of thromboembolic complication - stroke - was registered in the group A; it did not lead to lethal consequences. Among the group B patients 24 thromboembolic complications occurred (stroke, prosthesis thrombosis), 13 of them having become lethal $(\mathrm{p}<0.05)$. 
Conclusions. The paper presents long-term results of 520 operations carried out because of mitral valve insufficiency due to the integrity damage of this valve chordal-papillary apparatus; the operations were made using different approaches during a decade (2006-2015). At first both groups of patients studied were without significant differences. The group B contained more patients with atrial fibrillation and associated ischemic heart disease suggesting higher illness severity in this group patients. The duration of aorta clamping and cardiopulmonary bypass was significantly lower in MVR cases versus plastics ones proving the lower MVR technical difficulty.

The authors traced the long-term results for $93.8 \%$ of patients discharged. The specific weight of good and satisfactory results in both groups was almost the same (about $80 \%$ of cases) proving the significant reliability of correction methods examined here. Unsatisfactory results among the group A patients were mainly due to disturbances of mitral valve function, such results among the group B patients being mostly due to thromboembolic complications associated with breaches and difficulties of anticoagulant therapy control and progressive heart failure.

The causes of long-term lethal cases in MVR patients became mainly thromboembolic complications and progressive heart failure. In patients with mitral valve plastics the dominant causes of lethal events were progressive heart failure and sudden death.

\section{References}

1. Дземешкевич С.Л., Стивенсон Л.У. Болезни митрального клапана. М.: Медицина, 2000. - С. 265-273.
2. Добротин С.С, Богданевич СВ., Земскова Е.П. Пути улучшения результатов протезирования митрального клапана сохранением задней створки и подкапанных структур// Вестник хирургии им. Грекова. - 2000. №3. - C. $12-15$.

3. Приходько В.П., Логаненко Д.И., Михайлов А.В., Молчанов А.Н., Медведев А.П., Широков М.В. Варианты хирургического лечения посттравматических пороков сердца // Патология кровообращения и кардиохирургия. - 2005. - № 4. - С. 18-22.

4. Соколов В.В. Имплантация протезов митрального клапана с сохранением подклапанных структур: Автореф.дис. ... канд.мед.наук. -М., 1990

5. Alfieri, O. and Lapenna, E. Systolic anterior motion after mitral valve repair: where do we stand in 2015? Eur J Cardiothorac Surg. 2015; 48: 344-346

6. Chan, V., Ahrari, A., Ruel, M., Elmistekawy, E., Hynes, M., and Mesana, T.G. Perioperative deaths after mitral valve operations may be overestimated by contemporary risk models. Ann Thorac Surg. 2014;98: 605-610.

7. David, T.E., Armstrong, S., and Ivanov, J. Chordal replacement with polytetrafluoroethylene sutures for mitral valve repair: a 25-year experience. J Thorac Cardiovasc Surg. 2013; 145: 1563-1569

8. De Bonis, M., Lapenna, E., Taramasso, M. et al. Is commissural closure associated with mitral annuloplastics a durable technique for the treatment of mitral regurgitation? A long-term ( $\leq 15$ years) clinical and echocardiographic study. J Thorac Cardiovasc Surg. 2014; 147: 1900-1906.

9. Wang, Z., Zhou, C., Gu, H., Zheng, Z., Hu, S. Mitral valve repair versus replacement in patients with rheumatic heart disease. J Heart Valve Dis. 2013;22:333-339.

\title{
Порівняльна оцінка віддалених результатів методик хірургічної корекції мітральної недостатності з порушенням цілісності хордально-папілярного контінууму
}

\author{
Большак О. О., Мнішенко В. І., Трембовецька О. М., Бешляга В. М., Леошко І. В., Попов В. В. \\ ДУ «Національний інститут серцево-судинної хірургії імені М .М. Амосова НАМН» (Київ)
}

\begin{abstract}
У роботі представлені результати хірургічного лікування 520 пацієнтів, яким виконано хірургічну корекцію мітральної недостатності з порушенням цілісності хордально-папілярного контінууму. Всі хворі були послідовно оперовані в умовах штучного кровообігу за період 01.01.2006-31.12.2015 pр. у різних відділах НІССХ імені М. М. Амосова. Всі простежені пацієнти були розподілені на дві групи: із пластикою мітрального клапана (група А); із протезуванням мітрального клапана (ПМК) (група Б).

Віддалені результати простежено у 487 пацієнтів (93,8\% від кількості виписаних). У роботі порівнюються віддалені результати різних методик хірургічної корекції мітральної недостатності з порушенням цілісності хордально-папілярного апарату. Метою роботи був аналіз віддалених результатів. 520 пацієнтів, послідовно оперованих за десятирічний період (2006-2015рр.), розділені на дві групи. До групи А (201 особа) включені пацієнти, яким виконана пластика мітрального клапана, в групу Б (319 осіб) - протезування мітрального клапана. Початково в групі Б було більше пацієнтів із фібриляцією передсердь та супутньою ішемічною хворобою серця, ніж у групі А. Відповідно серед пацієнтів групи Б виконано більшу кількість супутніх операцій коронарного шунтування. У групі А частіше виконувалася супутня пластика трикуспідального клапана, в основному при невеликій та помірній його недостатності. Віддалені результати простежені в терміни від 6 місяців до 10 з половиною років у 93,8\% пацієнтів. Обидві методики корекції зарекомендували себе як надійні, переважали хороші й задовільні результати в обох групах. Віддалені незадовільні результати та летальні випадки в групі А були пов'язані в основному з прогре-
\end{abstract}


Большак 0. О./ Порівняльна оцінка віддалених результатів методик хірургічної корекції мітральної ...

суючою серцевою недостатністю та порушенням функції мітрального клапана, в групі Б - 3 тромбоемболічними ускладненнями та прогресуючою серцевою недостатністю.

Ключові слова: пластика мітрального клапана, протезування мітрального клапана, хордально-папілярний апарат, віддалені результати.

\title{
Сравнительная оценка отдаленных результатов методик хирургической коррекции митральной недостаточности с нарушением целостности хордально-папиллярного континиума
}

\author{
Большак А.А., Мнишенко В.И., Трембовецкая Е.М., Бешляга В.М., Леошко И. В., Попов В. В. \\ ГУ «Национальный институт сердечно-сосудистой хирургии имени Н.М. Амосова НАМН Украины» (Киев)
}

В данной работе сравниваются отдаленные результаты разных методик хирургической коррекции митральной недостаточности с нарушением целостности хордально-папиллярного аппарата. Целью работы был анализ отдаленных результатов. 520 пациентов, последовательно оперированных за десятилетний период с 2006 по 2015 гг. разделены на 2 группы. В группу А (201 человек) включены пациенты, которым выполнена пластика митрального клапана, в группу Б (319 человек) - протезирование митрального клапана. Исходно в группе Б было больше пациентов с фибрилляцией предсердий и сопутствующей ишемической болезнью сердца, чем в группе А. Соответственно, среди пациентов группы Б выполнено большее количество сопутствующих операций коронарного шунтирования. В группе А чаще выполнялась сопутствующая пластика трикуспидального клапана, в основном при небольшой и умеренной его недостаточности. Отдаленные результаты прослежены в сроки от 6 месяцев до 10 с половиной лет у 93,8\% пациентов. Обе методики коррекции зарекомендовали себя как надежные, преобладали хорошие и удовлетворительные результаты в обеих группах. Отдаленные неудовлетворительные результаты и летальные исходы в группе А были, в основном, связаны с прогрессирующей сердечной недостаточностью и нарушением функции митрального клапана, в группе Б - с тромбоэмболическими осложнениями и прогрессирующей сердечной недостаточностью.

Ключевые слова: пластика митрального клапана, протезирование митрального клапана, хордально-папиллярный аппарат, отдаленные результаты. 